\title{
PREDICTING THERMAL PERFORMANCE OF ROOFING SYSTEMS IN SURABAYA
}

\author{
MINTOROGO, Danny Santoso \\ Department of Architecture, Petra Christian University - Surabaya, \\ Siwalankerto street, number 121-131, Surabaya, Indonesia \\ Email : dannysm@petra.ac.id
}

\begin{abstract}
Traditional roofing systems in the developing country likes Indonesia are still be dominated by the $30^{\circ}, 45^{\circ}$, and more pitched angle roofs; the roofing cover materials are widely used to traditional clay roof tiles, then modern concrete roof tiles, and ceramic roof tiles. In the 90's decay, shop houses are prosperous built with flat concrete roofs dominant. Green roofs and roof ponds are almost rarely built to meet the sustainable environmental issues. Some tested various roof systems in Surabaya were carried out to observe the roof thermal performances. Mathematical equation model from three references are also performed in order to compare with the real project tested. Calculated with equation (Kabre et al.), the $30^{\circ}$ pitched concreteroof-tile, $30^{\circ}$ clay-roof-tile, $45^{\circ}$ pitched concrete-roof-tile are the worst thermal heat flux coming to room respectively. In contrast, the bare soil concrete roof and roof pond system are the least heat flux streamed onto room. Based on predicted calculation without insulation and cross-ventilation attic space, the roof pond and bare soil concrete roof (greenery roof) are the appropriate roof systems for the Surabaya's climate; meanwhile the most un-recommended roof is pitched $30^{\circ}$ or $45^{\circ}$ angle with concrete-roof tiles roofing systems.
\end{abstract}

Keywords: Thermal performance; roofing systems.

\section{INTRODUCTION}

For century, pitched-roof-tile systems are mostly dominant to residential dwellings. Simple single-story and two-story houses are mostly built with pitched roof system. Majority pitched-roofs are dominantly built without any insulation, and the attic spaces could be vented or unvented, but unvented attic space are more likely to build. Only middle to high income societies' dwellings will be built with insulation and vented now; but it counts for only about 10 percentages. Commercial buildings such as, shophouses, office buildings, hotels, and apartments are built with flatted-concrete-roof system, and they are active buildings - applying air conditioning system. Especially with shop-houses or shop-offices, they were built boomingly on year of 1995 with two to three stories height. Likes low pitched-roofs, flattedconcrete-roofs are built without putting any insulation on the inside concrete surface or the ceiling materials on attic space. Causing great demand of air conditioning energy used on both active house and active buildings, the proper roofing systems have to be put more consideration at global warming and sustainable architecture issues.

\section{PROBLEMS}

\section{Mean Ambient Temperature}

Characterized by tropical zone along the equator, all cities in Indonesia will experience a typical hot- humid climate; town of Surabaya is no exception to it. Indonesia has only two seasons: the dry seasons (May-October) and the wet or rainy seasons (November-April). The diurnal temperature in coastal areas will be around $23^{\circ}-33^{\circ} \mathrm{C}$, where as in the highland, the temperature will be as low as $16^{\circ} \mathrm{C}$; the average daily temperature is about $26.61^{\circ} \mathrm{C}$ and the relative humidity will range from $61 \%$ to $95 \%$ (Setiadarma et al., 1995). Surabaya with latitude of $7^{\circ}$ $17-21^{\prime}$ 'South and longitudinal of $112^{\circ} 47^{\prime}$ East has been defined as equatorial tropic hot-humid climate in which the seasonal variation local climate in temperature and humidity will be small (Adamson et al., 1993). Based on three local weather stations: J (airport zone-Southern areas), P1 (center citycenter areas), P2 (harbor zone-Northern areas), the maximum temperatures of the three stations are around $33^{\circ}$ to $35^{\circ} \mathrm{C}$ and the minimum temperatures range $22^{\circ}$ to $24^{\circ} \mathrm{C}$ from 1993 to 2005 (Table 1). The diurnal temperature on rainy season is around $23^{\circ}$ $34^{\circ} \mathrm{C}$, and $20^{\circ}-33^{\circ} \mathrm{C}$ during the cool months, and $24^{\circ}$ $-37^{\circ} \mathrm{C}$ during the hottest months. The table 1 shows the minimum temperatures can be reached to $20^{\circ}-$ $21^{\circ} \mathrm{C}$ during 4 months which are June to August; at that time, the strong winter wind blows from Australia to Eastern part of Indonesia--Surabaya. Likewise the hottest months are October, November, and December. Rainy seasons commonly start on December and occasionally on November. 
Table 1. Average Maximum \& Minimum Temperatures (3 stations) of Surabaya 1993 - 2005

\begin{tabular}{|c|c|c|c|c|c|c|c|c|c|c|c|c|c|c|c|c|c|c|c|c|c|c|}
\hline & 1993 & & 1995 & & 1996 & & 1997 & & 1998 & & 1 & & 2001 & & 2002 & & 2003 & & 2004 & & 005 & \\
\hline Month & Max & Min & Max & Min & Max & Min & Max & Min & Max & Min & Max & Min & Max & Min & Max & Min & Max & Min & Max & Min & Max & Min \\
\hline 1 & 33.2 & 23.3 & 4.3 & 23.1 & 3.2 & 23.5 & 33.3 & 23.2 & 36.1 & 23.8 & 33.0 & 23.2 & 34.4 & 23.2 & 34.2 & 21.7 & 35.2 & 22.7 & 34.3 & 22.9 & 33.5 & 24.6 \\
\hline 2 & 33.5 & 23.2 & 33.6 & 23.0 & 32.9 & 23.3 & 34.0 & 24.3 & 34.7 & 23.3 & 33.3 & 23.5 & 4 & 23.4 & 6 & 23.3 & .9 & 22.9 & 9 & 2 & 33.2 & 23.9 \\
\hline 3 & 32.7 & 3.9 & 3.6 & 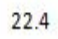 & 3 & 13 & 3 & 2 & 3 & 23. & 33.4 & 23 & 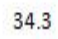 & 22 & 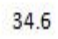 & 23 & 30 & 22.2 & 34.7 & .2 & 3 & 4.3 \\
\hline 4 & 32.9 & 24.0 & 34.3 & 22.6 & 33.9 & 23.7 & 33.6 & 23.6 & 35.2 & 24.4 & 33.3 & 23.9 & 34.3 & 23.4 & 34.8 & 23.4 & 34.9 & 23.9 & 34.8 & 23.8 & 32.6 & 24.3 \\
\hline 5 & 33.2 & 24.3 & 33.9 & 22.7 & 33.6 & 22.4 & 33.7 & 23.5 & 34.4 & 24.2 & 32.9 & 23.4 & 34.3 & 22.0 & 34.0 & 23.3 & 34.2 & 22.6 & 34.2 & 22.5 & 32.6 & 24.6 \\
\hline 6 & 32.8 & 2 & 3 & 2 & 32.8 & 7 & 7 & 2 & 3 & 1 & 2 & 23.6 & 33.2 & 22.2 & 33.8 & 5 & 5 & 21.0 & 7 & 5 & .5 & 24.5 \\
\hline 7 & 32.7 & 21.3 & 33.1 & 21.1 & 33.0 & 22.2 & 32.9 & 20.0 & 33.4 & 23.5 & 32.0 & 22.1 & 32.8 & 19.7 & 33.7 & 20.9 & 33.5 & 20.2 & 33.6 & 21.3 & 32.0 & 22.9 \\
\hline 8 & 32.3 & 22.2 & 33.0 & 20.8 & 33.8 & 22.1 & 32.0 & 20.0 & 34.1 & 23.0 & 33.0 & 21.2 & 33.1 & 20.6 & 33.2 & 20.0 & 34.0 & 19.8 & 33.4 & 20.3 & 32.4 & 22.7 \\
\hline 9 & 336 & 22.5 & 34.9 & 918 & 34.7 & 2 & 31 & 21 & 34 & 22. & 30 & 20.8 & 35.2 & 27 & 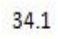 & 11 & 30 & 2 & 3 & 21.5 & 6 & 2 \\
\hline 10 & 35.3 & 23.5 & 35.6 & 22.6 & 35.3 & 23.9 & 36.4 & 20.1 & 34.6 & 23.9 & 34.7 & 22.7 & 35.4 & 23.5 & 36.9 & 21.9 & 36.3 & 22.9 & 36.7 & 22.3 & 34.4 & 24.0 \\
\hline 11 & 35.3 & 24.2 & 35.4 & 22.9 & 34.9 & 23.5 & 36.3 & 22.9 & 34.5 & 24.0 & 33.8 & 23.7 & 35.3 & 23.5 & 36.8 & 23.3 & 37.0 & 22.5 & 37.0 & 23.1 & 34.5 & 23.8 \\
\hline 12 & 34.5 & 23.8 & 34.0 & 22.8 & 34.1 & 23.7 & 36.0 & 23.6 & 34.8 & 23.7 & 33.8 & 23.7 & 34 & 23.1 & 35.9 & 23.3 & 34 & 22.9 & 35.3 & 23.0 & 32.7 & 23.9 \\
\hline Ave & 33.5 & 23.3 & 34.1 & 22.4 & 33.8 & 23.2 & 34.1 & 22.2 & 34.6 & 23.7 & 33.4 & 22.9 & 34.2 & 22.5 & 34.6 & 22.3 & 34.8 & 22.0 & 34.7 & 22.4 & 33.1 & 24.0 \\
\hline
\end{tabular}

(Source: Surabaya Weather Station)

The global warming characteristic happens to Indonesia also; town of Surabaya is no exception to it. The highest hot temperatures in 1993 during the dry seasons are approximately $35^{\circ}$ to $36^{\circ} \mathrm{C}$; whereas the highest temperatures are hotter two-degree centigrade in 2003 compare to the highest temperature in dry season 1993 (Fig. 1 and Fig. 2). The temperatures during the rainy seasons are from $32^{\circ}$ to $34^{\circ} \mathrm{C}$ in 1993 ; after 10 years, the rainy season temperatures in 2003 are $34^{\circ}$ to $36^{\circ} \mathrm{C}$. Those high ambient air temperatures will affect the thermal load on all kind of roofs.

Roofs will receive radiance heat loads from: the sol-air temperature, global and direct solar insolation, mean radiant temperature, and shape factor. Mackey et al. (1943) introduced initially the sol-air temperature, and then the sol-air temperature was altered by several researchers.

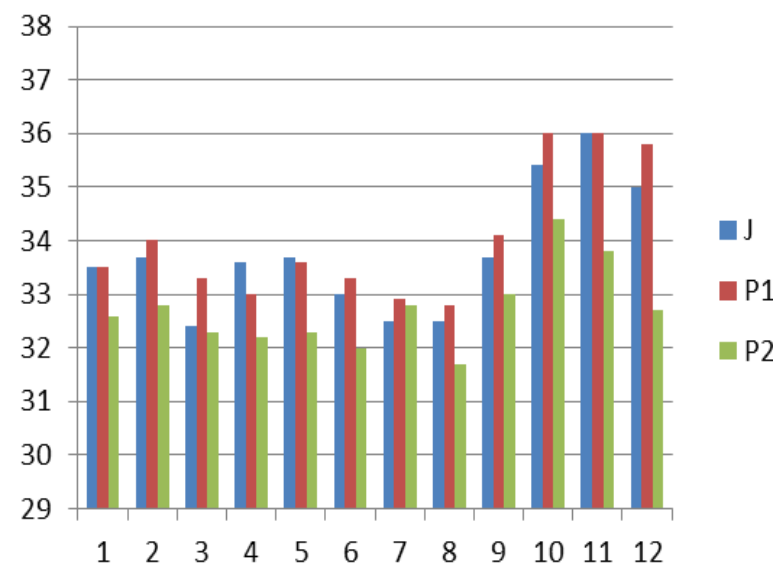

Fig. 1 Maximum Average Temperature of Surabaya in 1993, J (airport zone), P1 (city center zone), P2 (harbor zone)

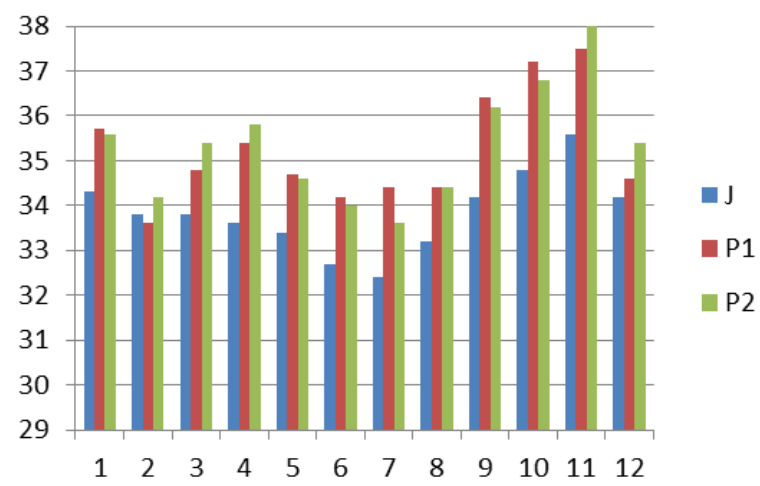

Fig. 2 Maximum Average Temperature of Surabaya in 2003

J (airport zone), P1 (city center zone), P2 (harbor zone)

The meaning of the sol-air temperature is the equivalency of the outdoor temperature that is causing the same rate of heat flux on a surface, and the same temperature is distributed through the material by net radiation exchange phrase (Kabre, 2010).

The equation of the sol-air temperature introduced by Kabre (2010) is:

$\mathrm{t}_{\mathrm{sa}}=\mathrm{t}_{\mathrm{oa}}+1 / \mathrm{f}_{\mathrm{o}}\left(\mathrm{I}_{\mathrm{g}} \cdot \alpha_{\sigma}-\varepsilon \cdot \Delta \mathrm{I}_{1}\right)$

Where:

$\mathrm{t}_{\mathrm{sa}}=$ sol-air temperature $\left({ }^{\circ} \mathrm{C}\right)$

$\mathrm{t}_{\mathrm{oa}}=$ outdoor mean ambient air temperature $\left({ }^{\circ} \mathrm{C}\right)$

$\mathrm{I}_{\mathrm{g}}=$ direct and global solar radiation incident on type of surface $\left(\mathrm{W} / \mathrm{m}^{2}\right)$

$\alpha_{\sigma}=$ solar absorptance of the material for short wave or solar radiation

$\mathrm{f}_{\mathrm{o}}=$ outside film or surface conductance $\left(\mathrm{W} / \mathrm{m}^{2} \mathrm{~K}\right)$

$\varepsilon=$ emittance of surface, usually taken as 0.9 for most building surfaces on low temperature 
radiation but only $0.05-0.2$ for low emittance surface Likes a polished metal

$\Delta \mathrm{I}_{1}=$ net long wave radiation exchange between a black body at outside air-temperature and the outside environment $\left(\mathrm{W} / \mathrm{m}^{2}\right)$

The value of the net long wave radiation $\left(\varepsilon . \Delta \mathrm{I}_{1}\right)$ has been defined by several researchers, and Building Research Station has been proposed for most precise educated guess of net long wave on horizontal surface as $95 \mathrm{~W} / \mathrm{m}^{2}$ for a cloudless sky, $15 \mathrm{~W} / \mathrm{m}^{2}$ for an overcast sky. For partially clouded sky, the net long wave value will be proportional to the cloud condition. (London, 1968; Kabre, 2010). Consequently the $\left(\varepsilon . \Delta \mathrm{I}_{1}\right)$ values will be:

$\varepsilon . \Delta \mathrm{I}_{1}=95-(95-15) \times \mathrm{m} / 8$

Where:

$\mathrm{m}=$ the cloud cover condition; and the $\mathrm{m}$ value ranges 0 to $8 ; m=0$ defines clear sky; $m=8$ indicates completely overcast sky condition.

The heat flux flows through an element for 1 meter square:

$\mathrm{Q}=\mathrm{A} \cdot \mathrm{U} \cdot\left(\mathrm{t}_{\mathrm{sa}}-\mathrm{t}_{\mathrm{a}}\right)$

Where: $\mathrm{Q}$ is heat flux $\left(\mathrm{W} / \mathrm{m}^{2}\right)$; the $\mathrm{t}_{\mathrm{sa}}$ is the $24 \mathrm{~h}$ mean sol-air temperature of outer surface, and $t_{a i}$ is the indoor temperature.

Another equation from Fourier's Law for calculating average heat flux transfer throught roofing materials is:

$\mathrm{q} / \mathrm{A}=\mathrm{U}\left(\mathrm{T}_{\mathrm{o}}-\mathrm{T}_{\mathrm{i}}\right)$

Where:

$\mathrm{U}=$ the overall heat transfer coefficient of the roofing material; $U=1 / R$

$\mathrm{T}_{\mathrm{o}}=$ the outdoor average ambient temperature

$T_{i}=$ the average indoor temperature

An alternative equation for caculated sol-air temperature $\left(\mathrm{T}_{\mathrm{r}}\right)$ with considering the solar radiation is absorbed by different roof orientation irradiation (Ciampi et al. 2003):

$\mathrm{T}_{\mathrm{r}}=\mathrm{T}_{\mathrm{o}}+\alpha \mathrm{r}_{\mathrm{ou}} \cdot \mathrm{I}$

Where $T_{0}$ is the shaded mean outdoor temperature, $\alpha$ is the outside surface solar radiation absorbability, and I is the solar irradiance on surface (horizontal, tilted orientation); $r_{\text {ou }}$ is the outer surface of the roof conductivity factor $\left(\mathrm{m}^{2} \mathrm{KW}^{-1}\right)$.

And the total thermal resistant, $R_{t 1}$ for unvented roofing system is as follows:

$\mathrm{R}_{\mathrm{tl}}=\mathrm{r}_{\mathrm{ou}}+\mathrm{R}_{\mathrm{A}}+\mathrm{R}_{\mathrm{B}}+\mathrm{r}_{\mathrm{in}}$

$R_{\text {ou }}$ and $r_{\text {in }}$ are the outer and inner of air surface of the roof; the $R_{A}$ and $R_{B}$ are the roofing materials and insulation respectively.
The mean heat flux passing the roofing materials to the unvented attic space is as follows:

$\mathrm{Q}=\left(\mathrm{T}_{\mathrm{r}}-\mathrm{T}_{\mathrm{in}}\right) / \mathrm{R}_{\mathrm{t} 1}$

Where: $Q$ is the heat flux $\left(\mathrm{W} / \mathrm{m}^{2}\right) ; \mathrm{T}_{\mathrm{r}}$ is the mean outer sol-air temperature, $\mathrm{T}_{\mathrm{in}}$ is the indoor temperature.

\section{Excessive Insolation}

The insolation is the amount of incident solar radiation energy received timely on a surface area which is horizontal or tilted one. The incident solar radiation energy is frequently articulated as an average irradiance in watts per square meter $\left(\mathrm{W} / \mathrm{m}^{2}\right.$ or $\mathrm{W} . \mathrm{m}^{-2}$ ) or kilowatt-hours per square meter per day $\left(\mathrm{kWh} / \mathrm{m}^{2}\right.$.day). A solar radiation measured on the outer surface of earth's atmosphere is called extraterrestrial radiation or solar constant, and it has roughly 1,366 W.m ${ }^{-2}$ (Time Series, 1978). The amount of solar radiation or solar irradiance intensity on earth's surface atmosphere will be affected by several conditions such as, cloud cover, water vapor, concentration of the $\mathrm{CO}_{2}$ in the air, smoke, and location's latitude. Solar radiation pierced the earth's atmosphere without interacting with atmospheric components is called direct insolation, whereas solar insolation scattered or reflected by atmospheric components is identified as diffuse or global irradiance. The solar radiation as a sun's ray is attenuated to approximately $1,000 \mathrm{~W} \cdot \mathrm{m}^{-2}$ for a surface perpendicular to the sun's ray. The amount of global solar irradiance on a location will depend intensely on sunshine duration. Surabaya's town has high enough percentages of sunshine duration throughout the year; an average of $70 \%$ to $80 \%$ of sunshine duration has been measured by three weather stations chronologically for 12 years (Fig. 3). During the rainy season (November - April), sun's ray percentage is still high to almost 55\% to 60\%, and in dry season (May October), sun's ray percentage is ranging from $70 \%$ to $99 \%$ (Fig. 4). Sunshine duration percentages will allocate directly to solar irradiance intensity. The higher the sun's ray percentage is in a day, the greater the global solar irradiance intensity will impact on all building's surfaces. The roof will receive the greatest heat radiant impacted than other parts of the building façade. That sun's ray will produce thermal heat on a surface that is absorbed or reflected by roof materials. Absorbed solar radiation will increase the outer surface temperature of the roof by 30 to $40^{\circ} \mathrm{C}$ (Adamson, 1993). 


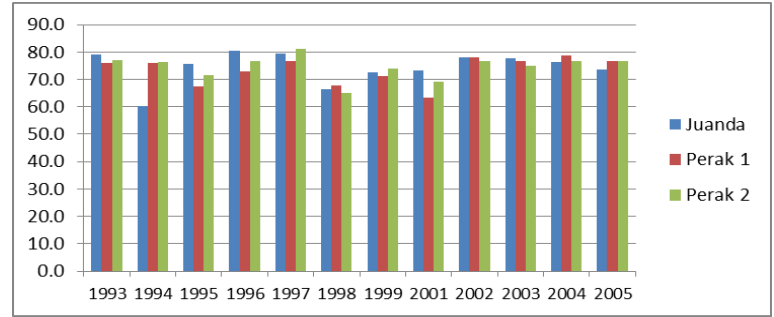

Fig. 3 Annually Average Sunshine Duration of Surabaya 1993 - 2005 J (airport zone), P1 (city center zone), P2 (harbor zone)

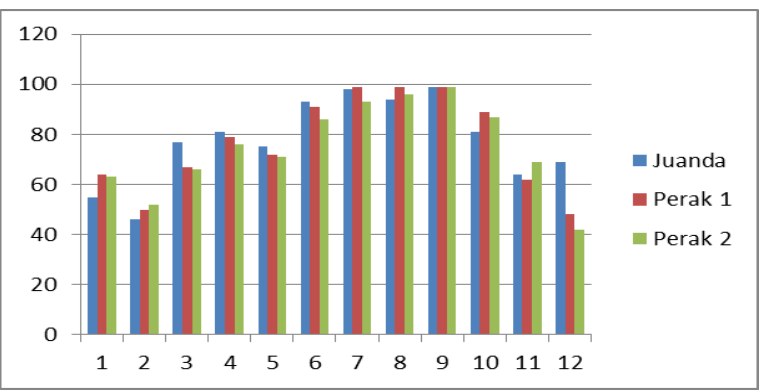

Fig. 4 Monthly Average Sunshine Duration of Surabaya 2003 J (airport zone), P1 (city center zone), P2 (harbor zone)

The surface of the opaque roofing material has three properties that are belongs to radiant heat exchange behaviors: the absorptivity, reflectivity, and emissivity. Perfect black roof surface will have higher absorptivity factor than white painted roof. The emissivity is the relative power of the material to emit radiant energy with a certain wavelength properties. The whitewash surface has absorptivity factor of 0.1 0.3 with respect to the shortwave sun's ray; whereas it has 0.95 of emissivity factor for the long-wave reflected sun's ray on any surface (Kabre, 2010).

The equatorial of Surabaya's average global solar radiation intensity on horizontal surface ranges from 300 to $400 \mathrm{~W} \cdot \mathrm{m}^{-2}$ per hour, and the total solar irradiance measured from 6 am to $6 \mathrm{pm}$ reaches about 4,000 to $5,500 \mathrm{~W} \cdot \mathrm{m}^{-2}$ per day. With latitude $7^{\circ} 21^{\prime}$ South, Surabaya's Eastern atmosphere has the highest concentration solar irradiance per hour and day with either tilt $30^{\circ}$ or $45^{\circ}$; the Southern part atmosphere has the least concentration solar irradiance all year round. Followed by Eastern atmosphere, the Northern side is the second highest concentration solar irradiance on almost tilt-angles per-hour or per-day (Fig. 5 through 8). The North side is the most effective atmosphere for acquiring solar irradiance from sunrise to sunset on solar water heater or photovoltaic appliances; whereas Eastern side is only half-day high concentration solar irradiance. The concentration of solar radiation intensity watt per square meter with tilted $15^{\circ}$ facing Northern atmosphere is greater than horizontal solar irradiance. Among the four tilted pyranometers facing North $-15^{\circ}, 20^{\circ}, 25^{\circ}, 30^{\circ}$, the $30^{\circ}$ tilted global solar irradiance is the highest concentration radiation; it ranges 400 to $500 \mathrm{~W} . \mathrm{m}^{-2}$ per hour, and having total 5,000 to $6,000 \mathrm{~W} \cdot \mathrm{m}^{-2}$ per day (Table 2). This solar irradiance will affect on mostly tilted $30^{\circ}$ pitch-roofs that cause huge amount of thermal heat of roofing temperature to attic space, then further affects to ceilling temperatures. Only when house with sharp roof pitch of $45^{\circ}$ tilt more, the solar irradiance intensity per hour will be cut one-third of the $30^{\circ}$ solar irradiance intensity (Fig. 5 and 7).

Table 2. Average Horizontal and Tilted North Global Solar Irradiance per Hour $\left(\mathrm{W} / \mathrm{m}^{2}\right)$ and Daily $\left(\mathrm{Wh} / \mathrm{m}^{2}\right)$ of 2009

\begin{tabular}{|c|c|c|c|c|c|c|c|c|c|c|}
\hline & Horizontal & & N15 & & $\mathrm{N} 20$ & & N25 & & N30 & \\
\hline & Hounty & Daily & Hourly & Daily & Hourly & Dally & Hourly & Daily & Hourly & Daily \\
\hline January & 306 & 3979 & 301 & 3913 & 288 & 3750 & 275 & 3577 & 286 & 3721 \\
\hline February & 268 & 3484 & 264 & 3428 & 255 & 3320 & 247 & 3209 & 265 & 3439 \\
\hline March & 339 & 4410 & 357 & 4644 & 352 & 4578 & 341 & 4431 & 381 & 4951 \\
\hline April & 337 & 4376 & 361 & 4691 & 363 & 4724 & 360 & 4678 & 422 & 5486 \\
\hline May & 292 & 3796 & 332 & 4312 & 335 & 4352 & 339 & 4409 & 402 & 5232 \\
\hline June & 337 & 4382 & 395 & 5134 & 402 & 5229 & 416 & 5402 & 499 & 6484 \\
\hline July & 357 & 4638 & 413 & 5375 & 423 & 5500 & 435 & 5656 & 524 & 6814 \\
\hline August & 384 & 4989 & 429 & 5576 & 430 & 5593 & 437 & 5677 & 522 & 6788 \\
\hline September & 424 & 5508 & 453 & 5894 & 445 & 5785 & 444 & 5766 & 512 & 6658 \\
\hline October & 409 & 5311 & 412 & 5355 & 399 & 5189 & 386 & 5018 & 426 & 5532 \\
\hline November & 344 & 4470 & 335 & 4356 & 321 & 4174 & 303 & 3938 & 329 & 4282 \\
\hline December & 321 & 4176 & 309 & 4012 & 295 & 3835 & 276 & 3590 & 297 & 3866 \\
\hline
\end{tabular}

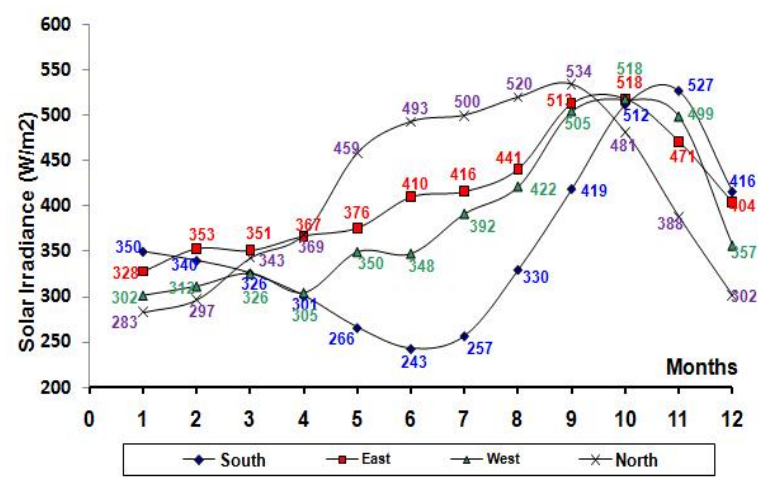

Fig. 5 Average Solar Irradiance $30^{\circ}$ per-hour $2006\left(\mathrm{Wh} / \mathrm{m}^{2}\right)$

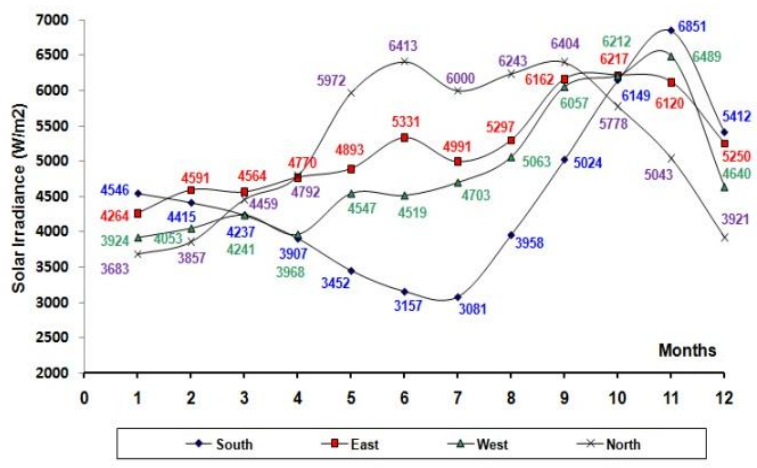

Fig. 6 Average Solar Irradiance $30^{\circ}$ per-day $2006\left(\mathrm{Wh} / \mathrm{m}^{2}\right)$ 


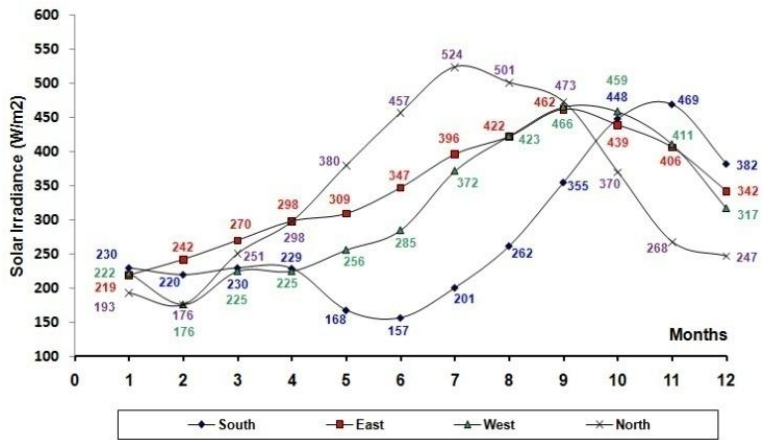

Fig. 7 Average Solar Irradiance $45^{\circ}$ per-hour $2006\left(\mathrm{~W} / \mathrm{m}^{2}\right)$

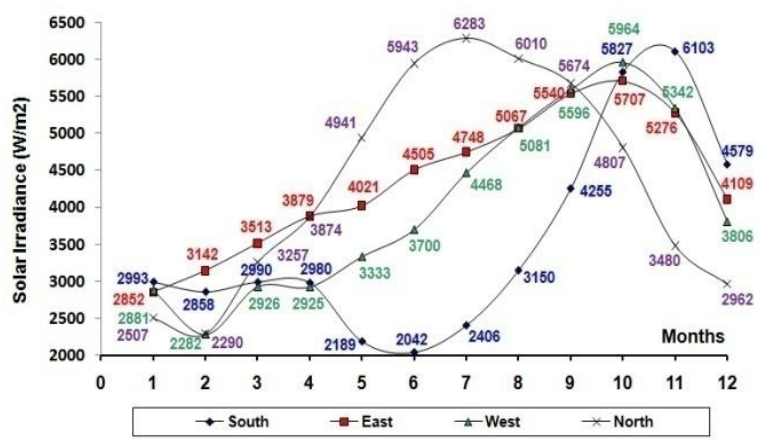

Fig. 8 Average Solar Irradiance $45^{\circ}$ per-day $2006\left(\mathrm{Wh} / \mathrm{m}^{2}\right)$

\section{LITERATURE REVIEW}

\section{Conventional Pitch Roofs}

Residential dwellings, terrace houses, and shop houses are commonly built with two-story level. Those buildings' roof systems are low or sharp pitch roof as well as flat roof. The huge amount of thermal heat radiant impacted to buildings will come from roofs in terms of inappropriate selection of roof materials and insulation systems in a certain climatic region; especially in hot and humid climate zone likes Surabaya town, the solar radiation protection for buildings remains the first priorty concern in energy saving domains (Lau et al., 2008; Puangsombut et al., 2007; Francois et al., 2004; Olgyay, 1992; Koeningsberger et al., 1980). Unfortunately there are no regulation required to built roofs with insulations in Surabaya city code. Almost 90 to $95 \%$ most houses and even shop houses with flat concrete roofs built without any radiant barrier. A research done by Allen Lau Khin Kiet et al. (December 2006 - March 2007) for housings with $30^{\circ}$ roof-pitch in state of Selangor and Kuala Lumpur Malaysia measured the MRT (Mean Radiant Temperature) inside the houses without and with certain kinds of insulation. First tested is for roof covering materials for terrace, semi detached, cluster, and bungalow houses without any insulation; the lowest MRT is $28.3^{\circ} \mathrm{C}$ for all types of roof materials - clay tile, concrete tile, metal deck-at $6 \mathrm{am}$. The outcome of the MRT at the hottest hour is taken at 2-3 pm; the clay-roof-tile houses have the lowest $31.9^{\circ} \mathrm{C}$ MRT. Then the concrete-roof-tile houses are $32.4^{\circ} \mathrm{C}$. Finally the metal deck roofing has the highest MRT of $33.2^{\circ} \mathrm{C}$. Second tested on concrete-roof-tiles only with reflective insulations. With single sided alluminium foil installed, the MRT is $28.5^{\circ} \mathrm{C}$ at $3 \mathrm{pm}$. The MRT could be low as $28.1^{\circ} \mathrm{C}$ at $3 \mathrm{pm}$ if it is installed with double sided alluminium foil. The lower state of MRT at 6 am for double sided aluminium foil is $25.8^{\circ} \mathrm{C}$.

Another research roof thermal performance on two-story house $30^{\circ}$ roof-pitch concrete tile with insulation underneath roof tiles and top of ceiling cover at Klang Valley Malaysia has been conducted by Nor Zaini Zakaria at al. (2008). With putting radiant barrier as of $10 \mathrm{~mm}$ to $100 \mathrm{~mm}$ underneath the concrete tiles, the attic roof temperature is blocked by $6,7^{\circ} \mathrm{C}$ on $100 \mathrm{~mm}$ insulation compared to $10 \mathrm{~mm}$ one; and the room temperature (MRT) is only $0.3^{\circ} \mathrm{C}$ difference. By laying $10 \mathrm{~mm}$ to $100 \mathrm{~mm}$ rockwood on top of the ceiling cover, the attic temperature increases by $1.8^{\circ} \mathrm{C}$ (from $43.4^{\circ} \mathrm{C}$ to $45.2^{\circ} \mathrm{C}$ ). This phenomena indicates the rockwood to block effectively thermal heat radiant from attic room to ceiling room below.

\section{Green Roofs or Rooftop Gardens}

There are no regulation or written building codes for constructing green roofs in Indonesia till now. No green roofs or rooftop gardens are allowed to build on government and public commercial buildings along the main business roads; it permits only on private dwelling-cluster-developers (Greenship, 2010).

In contrast to Germany, about $17 \%$ of new constructed buildings have been equipped with green roofs; it is projected up to 140 million square feet of green areas (Dawson, 2002). Meanwhile by 2005, roughly $20 \%$ of the existing and renovated flat roof buildings are changed to rooftop gardens in Basel, Switzerland (Brenneisen, 2005). In United Stated, city of Chicago, the green roofs have been existed for nearly 3 millions square feet of green area (Tayler, 2007).

Many researches on rooftop garden were carried out and they showed a great benefit to reduce cooling energy consumption for buildings. Rooftop gardens is not merely for cooling energy savings but also for making greenery built environment or less urban heat island. Rooftop garden have two kinds of greenery roof systems that are extensive and intensive green roofs. Extensive green roof characteristic is not to design for public excess, it is merely for aesthetic and 
ecological environment proposes, low-cost due to lightweight construction, low maintenance, thin layer of soil, and smaller vegetation (merely bushes). Contradictory to extensive green roofs, intensive green roofs are designed for public excess-way or roof garden-playground on rooftop parking buildings, high plants (scrubs or trees), thick substrate, heavyweight construction, and high maintenance (Wong, 2006; Czemiel Berndtsson, 2010).

Tested on intensive roof garden landscaping on low-rise commercial building, the maximum hard surface temperature (without soil and plants) at $2 \mathrm{pm}$ is $57^{\circ} \mathrm{C}$; the maximum bare soil surface temperature is $42^{\circ} \mathrm{C}$. With the presence of vegetation that is totally depended on the Leave Area Index (LAI), higher temperature will be happened on meager foliages and lower temperature is on intense ones. The maximum temperature on all kinds of vegetation under foliages is about $36^{\circ} \mathrm{C}$; and the maximum soil temperature with plants is $26.5^{\circ} \mathrm{C}$ (Wong, 2006).

With extensive rooftop garden, the maximum temperature on metal roof is $60^{\circ}-70^{\circ} \mathrm{C}$. By providing plants or vegetation, the maximum temperature below the dense plants is $35.1^{\circ} \mathrm{C}$. But the metal roof has the faster cooling effect at night among the other roof materials. Moreover metal roof is lightweight structure and has a low maintenance factor.

The structures are to be supported the concrete roof and weight of different depth of soils - intensive and extensive systems (Table 3); the weight of the dry to wetted soil layer is $1,700 \mathrm{~kg} / \mathrm{m}^{3}$; whereas the wet gravel, webbing or geotextile filter, and drainage material are around $1,450 \mathrm{~kg} / \mathrm{m}^{3}$; the small plants or lawns layer could be ignored (Table 4). Thus greenroof structures ought to have much more strength than other roof systems ones - pitch roofs and roof ponds. Czemiel Berndtsson (2010) showed the soil thickness needed by the extensive and intensive rooftop garden on table 3 ; it has been defined by several authors:

Table 3. The Soil Thickness for Intensive and Extensive Vegetation Rooftop Garden

\begin{tabular}{ccl}
\hline Extensive Soil $(\mathbf{m m})$ & Intensive Soil $(\mathbf{m m})$ & References \\
\hline $30-140$ & $150-350$ & Mentens et al. 2006 \\
$50-150$ & $150-1200$ & Kosareo and Ries 2007 \\
$<100$ & $>100$ & Wong et al. 2007 \\
$20-100$ & $>100$ & Graham and Kim 2005 \\
- & $>300$ & Bengtsson et al. 2005 \\
- & $>500$ & Kohler et al. 2002 \\
\hline
\end{tabular}

(Source: Czemiel Berndtsson, 2010)

Niachou et al. (2001) had accomplished thermal properties of green roofs and energy savings of buildings. Two types of vegetation of thick dark green and sparse red are used. It turned out to be the thick dark green roofing vegetation was effective to lower the roof surface temperature than the sparse red vegetation. Another green roof research of various types of sedum species (lava, arkalyte, pumice) and growth media (kamtchaticum, spurium, sexangulare) were carried out to show the reduction of summer heat flux cooling loads on the insulation of growth media of $80 \mathrm{~mm}$ (Celik et al., 2008). The outcomes showed that the lava rock and sedum spurium combination type had the best result on insulating heat flux on green-roofing-concrete. The energy costs could be saved to US $\$ 15 / \mathrm{h}$ on the hottest summer month of August with a US 8 cent per KWh. Research on plants and growing medium for reducing thermal green roof membrane has been conducted successfully by (Liu K., 2003) with aplying direct shading, getting evaporative cooling from the vegetattion, and attaching more insulation with growing medium to the flat roof.

\section{Roof Ponds}

Roof pond is a body of water on a roof structure which could be made of concrete or metal that cools a building by evaporative cooling effects. Instead of using evaporative cooling effects directly to humidify and cool the ambient air introduced to buildings, roof pond massing with cooled water on rooftop is chilled by conduction effects across the roof; this belongs to indirect evaporative cooling. The humidity will not be affected directly to part of room elements -walls, floors, and furniture (Givoni, 1994).

The roof pond cooling technique was first developed by Harold R. Hay (1973). He demonstrated the potential for $100 \%$ comfort with no need air conditioning during the daytime and nighttime in a Southwest house built with embodied in the skytherm.

According to Givoni (1994), roof pond has advantage systems, such as no orientation is needed for getting cooling or heating performances on flat rooftop, and the groundwater can be used, if the location is lack of water. Whilst the disadvantages are, roof pond has only cools straightforwardly space under rooftop, and the structures have to be had supporting weight of $200-400 \mathrm{~kg} / \mathrm{m}^{2}$; the concrete rooftop has required water proofing treatment (Spanaki, 2007).

Calculated with table 4, the construction weight of Pitched conventional concrete roofing tiles with steel truss would be approximate $1,000 \mathrm{Kg} / \mathrm{m}^{2}$, the extensive green roof with concrete $200 \mathrm{~mm}$ thick-slab roofing systems (300 mm wetted soil layer, and 400 $\mathrm{mm}$ geotextile and gravel drainage layer) is around $1,600 \mathrm{Kg} / \mathrm{m}^{2}$. Then the roof pond with $300 \mathrm{~mm}$ water depth with concrete slab thick $150-200 \mathrm{~mm}$ would be around $800 \mathrm{Kg} / \mathrm{m}^{2}$. 
Table 4. The Building Materials and Construction Weight

\begin{tabular}{|l|r|l|r|}
\hline \multicolumn{1}{|c|}{ Building Materials } & $(\mathrm{Kg} / \mathrm{m} 3)$ & Constructions & ( Kg/m2) \\
\hline Sands (dry to wetted) & 1,600 & Brick Walls 300mm & 450 \\
\hline Sands (wetted) & 1,800 & Brick Walls 150mm & 250 \\
\hline Gravel & 1,450 & Ceramic-tiles Floor with Cemen & 24 \\
\hline Soils (dry to wetted) & 1,700 & Roof-tiles with Wood-Rafter & 50 \\
\hline Mountain stones & 1,500 & Steel decking without Rafter & 10 \\
\hline Concrete & 2,200 & Shingles Roof with Rafter & 40 \\
\hline Concrete with steels & 2,400 & Asbestos Cemen Roofing 5mm & 11 \\
\hline Steels & 7,850 & Glass 3-4mm & 10 \\
\hline Bricks & 1,700 & & \\
\hline Alluminium & 2,800 & & \\
\hline Water & 1,000 & & \\
\hline & & & \\
\hline
\end{tabular}

Roof pond has already been proven to be more effective cooling system to reduce cooling loads from rooftop and thermal comfort than other passive cooling systems. Many innovative roof ponds have been developed from the base case-covered and uncovered panels.

\section{Uncovered pond with spray system.}

Open or uncovered pond with insulation panels is the simplest system but it has disadvantages of the blowing leaves, dust, algae and mosquito larvae. According to Roofsol (Roof Solution for Natural Ventilation) project researched by European country (Yannas, 1998, 2006; Spanaki, 2007), the open roof pond equipped with spraying system should be placed $0.5 \mathrm{~m}$ height, and has a 1 to 1.5 water volume exchanged rate per hour; the spray must be stopped when the water pond temperature reached to $3-4^{\circ} \mathrm{C}$ above the ambient WBT, otherwise the water pond will be warming up.

\section{Uncovered pond without spray system}

With this variant of roof pond system, the water depth shoud not $<300 \mathrm{~mm}$, and it is recommended to have $300 \mathrm{~mm}$ depth because the water will be warm up due to absorb the heat solar radiation during the daytime. The heat absorbed will be conversed with proportion to the underneath reflective pond factor. Nevertheless this system is cooled rapidly by evaporative and covective cooling effects of blowing wind over the upper water surface. The water pond temperature will have a fluctuation temperature of $5^{\circ} \mathrm{C}$ (Yannas, 1998, 2006; Spanaki, 2007).

There are other variations of cover with and without spraying the water ponds; both cooling performance with insulation cover panels rely directly to the emissivity, absorptivity factors and the air gap between panels and the water pond.

\section{Skytherm}

Roof pond that uses the function of nocturnal skytherm cooling system is made up of horizontal metal deck with water plastic bags laid over the metal deck, and it has insulation panels that will protect the water bags during the daytime; all insulation panel will be opended at night for gaining the long-wave night radiation. The depth of bags is suggested to range from 100-250 mm; the cooling performance is actually not too respond to variant depth of the water bags (Tang et al., 2005). Due to metal deck is galvanized sheet, the metal deck has to be covered with thin plastic sheet likes double laminated polyethylene sealed at the edges and a thin asphalt emulsion. A studied showed that house could mantain a indoor temperature below $30^{\circ} \mathrm{C}$ with the maximum outdoor dry-bulk temperature above $40^{\circ} \mathrm{C}$ for hot arid climate of New Delhi (Raeissi et al., 2000).

\section{Coolroof}

It was invented by Dick Bourne in 1980, Davis, California. This system uses concrete roof as roof pond with impermeable floating insulation panels in water; the water is then pumped over the insulation during the night in order to have long-wave sky radiation cooled the water. The cooling water temperature could be around $1-2^{\circ} \mathrm{K}$ above the average ambient WBT, and the ceilling temperature (exposed concrete) would have about $2^{\circ} \mathrm{K}$ over the water temperature (Givoni, 1994). An indoor temperature of $25^{\circ} \mathrm{C}$ would be obtained with the maximum outdoor temperature of $37^{\circ} \mathrm{C}$ during the daytime; the water pond temperature will fluctuate a round $5^{\circ} \mathrm{C}$ (Givoni, 1994).

\section{Forced Ventilation on closed-Roof pond}

Covered the roof pond with insulation panel at daytime, and open it to nighttime, a research had been done by Niles (1976). Therefore this experiment of roof pond was also equipped with insulation panels over the rooftop pond, but it was employed forced ventilation to blow air over top water pond that is within the shading panels and the pond in hot arid climate of central Iraq. The air gaps are $500 \mathrm{~mm}$ and $200 \mathrm{~mm}$ respectively on each other sides (Kharrufa et al., 2006). The research tested on two-story house with flat concrete roof. Tested on ordinary roof (without roof pond), the room temperature was minimum of $39.5^{\circ} \mathrm{C}$ and maximum $44^{\circ} \mathrm{C}$; at that time the outdoor temperature was minimum of $32^{\circ} \mathrm{C}$ and maximum of $44^{\circ} \mathrm{C}$. Conducted with roof pond but no cover and forced fan, the water pond temperature was of minimum $19^{\circ}$ to the maximum $34.5^{\circ} \mathrm{C}$ whilst the outdoor temperature was $26.5^{\circ}-41^{\circ} \mathrm{C}$ respectively minimum to maximum. Final combination of roof 
pond cooling with panel covered and forced ventilation installed, the water pond temperature was of minimum $19^{\circ} \mathrm{C}$ to maximum of $28.5^{\circ} \mathrm{C}$. At the same time the outdoor temperature was of minimum $28^{\circ} \mathrm{C}$ to maximum of $37^{\circ} \mathrm{C}$. The room temperature could be reached to minimum $34^{\circ} \mathrm{C}$ and maximum $37^{\circ} \mathrm{C}$.

\section{METHODOLOGY}

\section{Mathematical Model}

Thermal performance of various roofing types in Surabaya's town with the high percentages of sunshine durations, diurnal outdoor ambient temperatures, soaring direct and global solar irradiation will be examined with many kinds of sol-air temperature equations. The mean minimum and maximum ambient outdoor temperature for 11 years are $22.8^{\circ} \mathrm{C}$ and $34.1^{\circ} \mathrm{C}$ respectively $=\mathrm{T}_{\mathrm{o}}$ (Table 1$)$. The average indoor temperature $\left(\mathrm{T}_{\mathrm{i}}\right)$ is $30.6^{\circ} \mathrm{C}$; meanwhile the average relative humidity is $59.3 \%$ (measured). The Solar absorptance $\left(\alpha_{\sigma}\right)$ of the material for short wave or solar radiation for clay, concrete, soil, green grass, and water are 0.86, 0.60, 0.86, 0.74, and 0.93 respectively (Table 5). So the emissivity ( $\varepsilon$ ) values of materials surface can be seen on table 5 . The value of the net long wave radiation $\left(\Delta \mathrm{I}_{1}\right)$ for clear sky is 0 ; and for completely overcast sky is 15 (equation 2 ).

Table 5. Solar Absorptivity and Emissivity Surfaces

\begin{tabular}{lcc}
\hline \multicolumn{1}{c}{ Material } & $\begin{array}{c}\text { Solar Absorptivity } \\
\left(\alpha_{\sigma}\right)\end{array}$ & $\begin{array}{c}\text { Solar Emissivity } \\
(\varepsilon)\end{array}$ \\
\hline Clay & 0.86 & 0.75 \\
New Concrete & 0.60 & 0.88 \\
Old Concrete & 0.75 & 0.94 \\
Red Brick & 0.63 & 0.93 \\
Soil, earth & 0.86 & $0.93-0.96$ \\
Green grass & 0.74 & 0.50 \\
Water, deep & 0.93 & $0.95-0.96$ \\
\hline
\end{tabular}

(Source: Cengel, 1998, Table 9-13,12-6,A-14,A-15; Kreider and Rabl, Ref.3,Table 6)

By using equations from Kabre (2010), Fourier's Law, and Ciampi et al. (2003), the heat flux passed through unvented and un-insulated roof condition could be calculated (Table 6).

\section{Results}

By predicted calculation, heat flux $(\mathrm{Q})$ in clear sky by (Kabre, 2010) is high on pitched $30^{\circ}$ concrete-rooftile of $11.2 \mathrm{~W} . \mathrm{m}^{-2}$; pitched $30^{\circ}$ clay-roof-tile of 10.27 W. $\mathrm{m}^{-2}$ (as identical on calculated of the highest solar radiation concentration angle of $30^{\circ}$; table 2 ).
Table 6. Calculated Mean Heat Flux from Three Different Equations

\begin{tabular}{|c|c|c|c|c|c|}
\hline & \multicolumn{2}{|c|}{ Sol-air Temperature } & \multirow{2}{*}{$\begin{array}{l}\text { Heat Flux (Q) } \\
\text { (Kabre) }\end{array}$} & \multirow{2}{*}{$\begin{array}{c}\text { Heat Flux (Q) } \\
\text { (Fourier's Law) }\end{array}$} & \multirow{2}{*}{$\begin{array}{l}\text { Heat Flux (Q) } \\
\text { (Ciampi et al.) }\end{array}$} \\
\hline & & & & & \\
\hline & Clear sky & Overcast sky & Clear sky & Clear sky & Clear sky \\
\hline & $\left({ }^{\circ} \mathrm{C}\right)$ & $\left({ }^{\circ} \mathrm{C}\right)$ & $\left(w / m^{2}\right)$ & $\left(w / m^{2}\right)$ & $\left(w / m^{2}\right)$ \\
\hline Pitched $30^{\circ}$ Clay-roof-tile & 39.0 & 27.7 & 10.27 & 4.50 & 15.63 \\
\hline Pitched $30^{\circ}$ Concrete-roof-tile & 39.9 & 26.7 & 11.2 & 4.77 & 11.94 \\
\hline Pitched $45^{\circ}$ Clay-roof-tile & 38.2 & 26.7 & 9.27 & 4.29 & 13.50 \\
\hline Pitched $45^{\circ}$ Concrete-roof-tile & 38.9 & 25.7 & 10.22 & 4.30 & 10.43 \\
\hline Flat Concrete roof & 38.9 & 25.7 & 10.92 & 4.63 & 13.60 \\
\hline Green Concrete-roof (extensive) & 37.4 & 29.9 & 4.50 & 2.31 & 22.19 \\
\hline Bare Soil Concrete-roof & 38.2 & 24.3 & 5.7 & 2.64 & 21.86 \\
\hline Concrete Roof Pond & 40.4 & 26.1 & 6.4 & 2.30 & 27.15 \\
\hline
\end{tabular}

The green roof with extensive one is the lowest heat flux of $4.50 \mathrm{~W} . \mathrm{m}^{-2}$, and then follows by the roof pond of $6.4 \mathrm{~W} \cdot \mathrm{m}^{-2}$. Meanwhile heat flux by (Fourier's Law), the roof pond is the lowest of $2.30 \mathrm{~W} . \mathrm{m}^{-2}$, then green roof of $2.31 \mathrm{~W} / \mathrm{m}-2$. The $45^{\circ}$ pitched clay and concrete-roof tile are greater than $30^{\circ}$ pitched angle clay and concrete-roof tile of 4.29, 4.30, 4.29, 4.23 W. $\mathrm{m}^{-2}$ respectively. The most different outcome heat flux (Q) by (Ciampi et al., 2003) of the roof pond thermal performance is the huge one compare to others of $27.15 \mathrm{~W} . \mathrm{m}^{-2}$. The green roof is also greater then concrete-roof-tile of $22.19 \mathrm{~W} \cdot \mathrm{m}^{-2}$. So the clayroof-tile is higher heat flux than that of concrete roof tile. Overall, Ciampi's equation seems to be contradicted to other equations even with the measured outcomes. The closer predicted to measured thermal performance is the Kabre's equation on sol-airtemperature and heat flux. Both the solar absorptance, emittance of particular roof material surface and the direct and global solar incident from many directions are counted by Kabre's equation. The thermal resistance of the outside air is used to resist by convection. Moreover the net long wave radiation is considered for giving values of clear or overcast sky in particular local climate situation likes Surabaya's climate.

\section{Conclusions and Further Development}

Owing to the predicted mathematically model results, it is evidently that the pitched $30^{\circ}$ angle concrete-tile roofing system has the worst thermal performance on either surface temperatures or heat flux to room. Right after the most awful thermal performance of concrete-tile-roof is the concrete flat roof; this roof system has been installed on many of shop-houses and roof top commercial buildings likes apartments and hotels as well as rental offices. The hand-made traditional clay-roof-tiles have better thermal performances than the industrial- modernmade of concrete-roof-tiles; concrete-roof-tiles are thicker than clay-roof-tiles, and concrete tiles has 
longer thermal lag than clay one. The most prominent thermal behaviors are the green roofs and roof pond; the green roofs have many more complicated substructures to construct than the roof pond. The green roofs are also having more loads (wet soil and gravel) than the water agent at roof pond.

Further investigated of sustainable roofing systems in terms of energy savings in the tropical climate of Surabaya town could be performed.

\section{ACKNOWLEDGMENT}

I would like to express my gratitude to prof. Mohd. Hamdan for his kindness and considerable time to made this report done.

\section{REFERENCES}

Adamson, B., \& Olle, A. (1993). Design for Climatization; Houses in Warm-Humid Areas. Building Issues, $\mathbf{5}(1)$.

Bengtsson, L., Grahn, L., \& Olsson, J. (2005). Hydrological Function of a Thin Extensive Green Roof in Southern Sweden. Nordic Hydrology, 36(3), 259-268.

Brenneisen, S. (2005). The World Green Roof Congress and Green Roof Week, $1^{\text {st }}$ World Green Roof Congress, Opening Session.

Cengel, Y.A. (1998). Heat Transfer: A Practical Approach. McGraw Hill Company, New Jersey.

Celik, S.S., Morgan, W. A. \& Retzlaff (2008). Energy Conservation Analysis of Various Green Roof Systems.

Czemiel Berndtsson, J. (2010). Green Roof Performance Towards Management of Runoff Water Quantity and Quality: A Review. Ecological Engineering, oi:10.1016/j.ecoleng.2009.12.014.

Dawson, D. (2002). Plant-covered Roofs Ease Urban Heat, National Geographic News.

Francois, G., Laetitia, A., Boyer, H., \& Rat, C. (2004). Implementation and Experimental Survey of Passive Design Specifications Used in New Low-cost Housing Under Tropical Climate. Energy and Buildings, 36, 353-366.

Givoni, Baruch (1994). Passive and Low Energy Cooling of Buildings. Van Nostrand Reinhold, New York.

Graham, P., \& Kim, M. (2005). Evaluating the Stormwater Management Benefits of Green Roofs Through Water Balance Modeling. In: Green roofs for Healthy Cities Conference, New York.

Kabre C. (2010). A New Thermal Performance Index for Dwelling Roofs in the Warm Humid
Tropics. Building and Environment, 45, 738727.

Koeingsberger, O.H., Ingersoll, T.G., Mayhew, A., \& Szokolay, S.V. (1980). Manual of Tropical Housing and Building, Part 1 Climatic Design. London, Longman.

Kh, V.S. (1995). Civil Engineering Standard Book. Bandung, Nova.

Kharrufa, S.N., \& Yahyah, A. (2006). Roof Pond Cooling of Buildings in hot Arid Climates, Building and Environment, 43, 82-89.

Kohler, M., \& Ries, R. (2007). Comparative Environmental Life Cycle Assessment of Green Roofs . Building and Environment, 42, 2606-2613

Kosareo, L., Schmidt, M., Grimme, F.W., Laar, M., de Assuncao Paiva, V.L., \& Tavares, S. (2002). Green Roofs in Temperate Climates and in the Hot-Humid Tropics - Far Beyond the Aesthetics . Environment Management Health, 13(4), 382391.

Lau, A.K.K., Elias, S., \& Lim, C.H. (2008). Thermal Performance Evaluation of Roofing Systems and Materials in Malaysia Residential Development. In: Proceeding of $9^{\text {th }}$ SENVAR and $2^{\text {nd }}$ ISESEE Humanity and Technology, Shah Alam, Malaysia, 387-395.

Liu, K. (2003). Engineering Performance of Rooftop Gardens through Field Evaluation, National Research Council Canada: Institute for Research in Construction.

Mackey C.O., \& Wright, L.T. (1943). Summer Comfort Factors as Influenced by the Thermal Properties of Building Materials. ASHRAE Transactions Heating, Piping \& AC Section, 49, 148-74.

Mantens, J., Raes, D., \& Hermy, M. (2006). Green Roofs as a Tool for Solving the Rain-Water. Runoff Problem in the Urbanized $21^{\text {st }}$ Century. Landscape Urban Planning, 77, 217-226.

M. Ciampi, Leccese, F., \& Tuoni, G. (2003). Ventilated Facades Energy Performance in Summer Cooling of Buildings, Solar Energy, 75, 491502.

Niachou, A.K., Papakonstantinou, M., Santamouris, A., Tsangrassouls, G. \& Mihalakakou (2001). Analysis of the Green Roof Thermal Properties and Investigation of Its Energy Performance, Energy and Buildings, 33, 719-729.

Niles, PWB. (1976). Thermal Evaluation of a House Using a Moveable Insulation and Cooling System, Solar Energy, 18 (5).

Olgyay, V. (1992). Design with Climate. New York, Van Nostrand Reinhold. 
Puangsombut, W., Hirunlabh, J., Khedari, J., Zeghmati, B., \& Win, M.M. (2007). Enhancement of Natural Ventilation Rate and Attic Heat gain reduction of Roof Solar Collector Using Radiant Barrier. Building and Environment, 42, 22162218.

Raeissi, S., \& Taberi, M. (2000). Skytherm: An Approach to Year-Round Thermal Energy Sufficient Houses, Renewable Energy, 19, 527-543.

Setiadarma, E. (1995). The Climatic Performance of Indonesian Traditional Architecture: A Comparison of Madurese and Javanese Architecture. In: Proceeding of National Solar Energy Conference, Minneapolis, Minnesota.

Spanaki, A. (2007). Comparative studies on Different Type of Roof Ponds for Cooling Purposes: Literature Review. In: Proceeding of $2^{\text {nd }}$ PALENC and $28^{\text {th }}$ AIVC Conference on Building Low Energy Cooling and Advanced Vebtilation Technologies in the $21^{\text {st }}$ Century, Crete Island, Greece.

Tang, R., \& Etzion, Y. (2005). Cooling Performance of Roof Ponds with Gunny Bags Floating on
Water Surface as Compared with a Moveable Insulation, Renewable Energy, 30, 1373-1385.

Tayler, D.A. (2007). Growing Green Roofs, City by City, Environmental Health Perspectives, 115 (6), 306-311.

Time Series. (1978). Construction of a Composite Total Solar Irradiance (TSI). (http://www. pmodwrc. ch/pmod.php?).

Wong, N.H., \& Chen, Y. (2006). A Comparison of Two Rooftop Systems in the Tropical Climate. In: Proceeding of the INTA $2^{\text {nd }}$ Harmony in Culture and Nature Conference, Indonesia, B14, 1-8.

Wong, N.H., Tan, P.Y., \& Chen, Y. (2007). Study of Thermal Performance of Extensive Rooftop Greenery Systems in the Tropical Climate. Building and Environment, 42, 25-54.

Zakaria, N.Z., Peter, W., \& Ahmad, R. (2008). Thermal and Energy Evaluation of Roofing and and Ceiling Insulation for Residential Building in Tropical Climate. In: Proceeding of $9^{\text {th }}$ SENVAR and $2^{\text {nd }}$ ISESEE Humanity and Technology, Shah Alam, Malaysia, 577-585. 